\title{
MEASURING THE PERFORMANCE OF PRIVATE PENSION SECTOR BY TOPSIS MULTI CRITERIA DECISION-MAKING METHOD
}

\author{
DOI: $10.17261 /$ Pressacademia.2018.937 \\ JEFA- V.5-ISS.3-2018(6)-p.288-295
}

\section{Burcu Gurol ${ }^{1}$, Muge Imam ${ }^{2}$}

${ }^{1}$ Baskent University, Faculty of Commercial Sciences, Banking and Finance Department, Ankara, Turkey. bgurol@baskent.edu.tr, ORCID:0000-0001-9974-2351

${ }^{2}$ Vakif Bank, Branch Operation, Ankara, Turkey.

tokatlimuge@gmail.com, ORCID: 0000-0001-9854-1726

Date Received: June 17, 2018

Date Accepted: September 10, 2018

To cite this document

Gurol, B., Imam, M. (2018). Measuring the performance of private pension sector by TOPSIS multi criteria decision-making method. Journal of Economics, Finance and Accounting (JEFA), V.5(3), p.288-295.

Permemant link to this document: http://doi.org/10.17261/Pressacademia.2018.937

Copyright: Published by PressAcademia and limited licenced re-use rights only.

\begin{abstract}
Purpose- In this study, a sector-based research has been conducted for the performances of private pension companies operated between 2006 and 2016, in Turkey. Moreover, the changes in sectoral performance have been analysed for the determined years and results interpreted.

Methodology- Performence has been analysed by using a multi criteria decision-making technique, TOPSIS. During the study, performance measurement factors have been determined as nine financial ratios below.

Findings- In the end of the analysis, performance scores for each year have been calculated and the results have been ranked. Therefore, ranks of each year examined in success rating have been identified. Among the years examined, 2008 has the highest performance while 2006 has the lowest.

Conclusion- When the results examined, it is observed that sector's performance have increased since 2013. In addition, the coefficient is thought to be state subsidy amounting to $25 \%$ of employees' paid contributions to private pension account, which was initiated on January 1 st, 2013.
\end{abstract}

Keywords: Multi criteria decision making techniques, private pension, private pension sector, TOPSIS.

JEL Codes: G20, G22, G23, M40, M49

\section{INTRODUCTION}

Private pension is a system that allows individuals to contribute from their earnings, and get retired after a while. In private pension system, the participant has the right to determine the contribution he/she is going to invest. Individuals participate in the system by signing private pension contracts. After having paid contributions for a particular time and having got to the statutory age, individuals qualify for a pension.

Personal (private) pension system has been performing in Turkey since October $27^{\text {th }} 2003$. Being a part of social security reform, it does not only serve that purpose, but also takes an important role in the improvement of financial system (işseveroğlu \& Hatunoğlu, 2010).

Being based on voluntary participation in Turkey, the total net asset value of the system's mutual funds reached to 53,4 billion TL in 2016, while it was 276 million in 2006. As of 2016, the number of participants partaking in the system was about 6, 6 million individuals. While the sector employed 12.135 people in 2006, the number of employees approached to 40.000 by the end of 2016. The sector achieved growth in comparison with the developed countries. When Turkey's population characteristics and the size of private pension systems in developed countries are considered, it is observed that the results are low. By the end of 2015, while the ratio of mutual pension fund assets' total value to gross national product was $5 \%$ in Turkey, the same ratio was over $170 \%$ in Netherlands in the same year. For this reason, it is considered that private pension system will continue its growth in Turkey. 


\section{LITERATURE REVIEW}

In his study where he evaluates the performances of life and non-life insurance companies operating in Turkish insurance sector by dividing them into two and using data envelopment analysis, Çiftçi concludes that the different efficiencies of insurance companies result from the big differences in scale efficiency and is rather a problem of those companies working inefficiently (2004).

In the end of their study where they measure multi criteria performances of private pension funds in Turkey between January 2007 and December 2008 with TOPSIS method, Alptekin and Şıklar sort those funds by their performances (2009).

In their study where they measure performance by grey relational analysis method, Peker and Baki, evaluate performance with the help of liquidity, leverage and profitability ratios and conclude that a company with high liquidity ratios could have high performance as well(2011)

Dalkılıç measures the efficiency of insurance companies operating in Turkey through 2008-2010 period by using data enveloping, data oriented, input oriented variable yield BCC model and total factor efficiency index. In this study, Dalkılıç concludes that in comparison with 2008, efficiency of insurance companies increased in 2009, while it went down in 2010 (2012).

Karakaya et al identify in their study where they measured efficiency degrees of 14 private pension companies in Turkey by using data enveloping analysis that, some companies are inefficient since they use their marginal capacities (2014).

In their study where they measure performances of 36 non-life insurance companies' operated in Turkey between 2011 and 2016 by using VIKOR method, Bülbül and Baykal have grouped the companies as steady and unsteady. Moreover, by identifying the possible factors that lead to performance changes, they have provided performance-improving suggestions (2017).

Köse and Türkel have provided performance-improving suggestions for low-performing companies in their study where they analysed the performance evaluations of 26 non-life insurance companies of Turkish Insurance Sector by Gray Relational Analysis Method in 2014-2016 period (2017).

In their study where they compare the performances of 15 pension companies operated in Turkey between 2012 and 2016 by using principal components and clustering analyses, Kırkağaç and Dalkılıç conclude that Ziraat Emeklilik ranked number nine and Anadolu Hayat Emeklilik had the highest performance in 2012. In addition, they state that Ziraat Emeklilik ranked first in the following years (2017).

Gürol and Hazar compare the performances of life and non-life insurance companies by using CAMELS method and conclude that the companies operating in the field of life/pension are more efficient than the ones that are active in nonlife/pension branch (2017).

Özaktaş evaluates the efficiency of insurance companies operated in Turkey between 2002 and 2015 by the help of three different data envelopment analyses. In this study, Özaktaş concludes that being listed or unlisted on the stock exchange does not create a major effect on insurance companies' efficiency degrees. In addition, Özaktaş states that efficiency degrees of foreign-invested companies are higher than the degrees of domestic ones only in portfolio management. Lastly, Özaktaş deduces that domestic corporations have higher averages than medium and small scaled ones (2017).

When foreign studies regarding the performance measurement of private pension companies are considered, it can be stated that, Barros and Garcia (2006), Teresa and Garcia (2010) Portugal; Barros, Ferro and Romero Argentina (2008); Wu, Yong, Vela and Liang (2007) Canada, Barrientos and Boussofiane (2005)Chile have conducted studies related to performance measure in pension sector.

\section{DATA AND METHODOLOGY}

In this study, TOPSIS multi criteria decision-making method has been used, in order to measure the performance of Turkey's private pension sector. Chen and Hwang (1991) presented TOPSIS method by referring to the Works of Hwang and Yoon (1981) (Demirelli, 2010).

TOPSIS is a technique that enables using the best choice among all alternatives. (Özdemir, 2015). In this technique, ideal and negative ideal solution values are determined via factor values that belong to the alternatives. Those alternatives are sorted according to their status with respect to ideal and negative ideal solutions.

During the study, performance measurement factors have been determined as nine financial ratios below. These ratios have been included in measurements as equiponderant. 
Table 1: Financial Ratios Used in Performance Measurement

\begin{tabular}{|l|}
\hline Shareholders Equity/Total Assets \\
\hline Financial Investments of Risk Life Insurance Policy/Total Assets \\
\hline Short Term Liabilities/ Total Assets \\
\hline Pension Technical Income/Pension Technical Expense \\
\hline Net Period Profit/Total Assets \\
\hline Net Period Profit/Shareholders Equity \\
\hline Net Period Profit/ Number of Sector Employees \\
\hline (Pension Technical Income-Pension Technical Expense)/Number of Participants \\
\hline Net Period Profit / Number of Contracts \\
\hline
\end{tabular}

When making analysis by TOPSIS method, the first step is to create decision matrix for each alternative together with the factor values determined.

$$
A_{i j}=\left[\begin{array}{ccc}
a_{11} a_{12} \ldots & a_{1 p} \\
a_{21} a_{22} \ldots & a_{2 p} \\
\cdot & \\
\cdot & \cdot \\
a_{m 1} a_{m 2} & \ldots & a_{m p}
\end{array}\right]
$$

See Table 2 for the Decision Matrix of this study.

\section{Table 2: Decision Matrix}

\begin{tabular}{|c|c|c|c|c|c|c|c|c|c|}
\hline & $\begin{array}{l}\text { Shareholde } \\
\text { rs } \\
\text { Equity/Tot } \\
\text { al Assets }\end{array}$ & $\begin{array}{l}\text { Financial } \\
\text { Investmen } \\
\text { ts of Risk } \\
\text { Life } \\
\text { Insurance } \\
\text { Policy/Tot } \\
\text { al Assets }\end{array}$ & $\begin{array}{l}\text { Short } \\
\text { Term } \\
\text { Liabilitie } \\
\text { s/ Total } \\
\text { Assets }\end{array}$ & $\begin{array}{l}\text { Pension } \\
\text { Technical } \\
\text { Income/Pensi } \\
\text { on Technical } \\
\text { Expense }\end{array}$ & $\begin{array}{l}\text { Net } \\
\text { Period } \\
\text { Profit/Tot } \\
\text { al Assets }\end{array}$ & $\begin{array}{l}\text { Net Period } \\
\text { Profit/Sharehold } \\
\text { ers Equity }\end{array}$ & $\begin{array}{l}\text { Net } \\
\text { Period } \\
\text { Profit/ } \\
\text { Number } \\
\text { of Sector } \\
\text { Employe } \\
\text { es }\end{array}$ & $\begin{array}{l}\text { (Pension } \\
\text { Technical } \\
\text { Income-Pension } \\
\text { Technical } \\
\text { Expense)/Numb } \\
\text { er of } \\
\text { Participants }\end{array}$ & $\begin{array}{l}\text { Net } \\
\text { Period } \\
\text { Profit / } \\
\text { Number } \\
\text { of } \\
\text { Contract } \\
\text { s }\end{array}$ \\
\hline 2006 & 0,11 & 0,55 & 0,48 & 0,45 & 0,01 & 0,08 & 6405,59 & $-137,33$ & 68,10 \\
\hline 2007 & 0,11 & 0,47 & 0,46 & 0,58 & 0,02 & 0,18 & \begin{tabular}{|l|}
16567,0 \\
8 \\
\end{tabular} & $-92,03$ & 130,56 \\
\hline 2008 & 0,11 & 0,41 & 0,45 & 1,01 & 0,02 & 0,17 & \begin{tabular}{|l|}
17857,2 \\
2 \\
\end{tabular} & 1,15 & 126,87 \\
\hline 2009 & 0,10 & 0,35 & 0,49 & 1,03 & 0,02 & 0,16 & $\begin{array}{l}17470,5 \\
9\end{array}$ & 5,56 & 124,19 \\
\hline 2010 & 0,10 & 0,28 & 0,48 & 1,15 & 0,01 & 0,14 & \begin{tabular}{|l|}
17963,5 \\
5 \\
\end{tabular} & 24,73 & 118,46 \\
\hline 2011 & 0,13 & 0,23 & 0,47 & 1,00 & 0,01 & 0,11 & \begin{tabular}{|l|}
19283,0 \\
4 \\
\end{tabular} & 0,12 & 117,20 \\
\hline 2012 & 0,11 & 0,20 & 0,49 & 1,02 & 0,01 & 0,12 & \begin{tabular}{|l|}
21663,2 \\
9 \\
\end{tabular} & 3,94 & 125,01 \\
\hline 2013 & 0,10 & 0,16 & 0,49 & 0,79 & 0,01 & 0,12 & \begin{tabular}{|l|}
17348,0 \\
8 \\
\end{tabular} & $-42,09$ & 98,59 \\
\hline 2014 & 0,09 & 0,12 & 0,38 & 0,87 & 0,01 & 0,15 & \begin{tabular}{|l|}
20591,1 \\
2 \\
\end{tabular} & $-24,75$ & 113,46 \\
\hline 2015 & 0,08 & 0,09 & 0,37 & 0,94 & 0,01 & 0,17 & \begin{tabular}{|l|}
22959,8 \\
7 \\
\end{tabular} & $-10,78$ & 117,40 \\
\hline 2016 & 0,07 & 0,08 & 0,37 & 1,03 & 0,02 & 0,23 & \begin{tabular}{|l|}
33320,8 \\
7
\end{tabular} & 5,43 & 169,74 \\
\hline
\end{tabular}


In order to prevent negative effects of decision matrix's value differences on the results of analysis, decision matrix is subjected to a normalization process. Normalization has been applied according to the formula below, and Table $\mathbf{3}$ represents the normalized matrix of the study.

$$
n_{i j}=\frac{a_{i j}}{\sqrt{\sum_{i=1}^{m} a_{i j}^{2}}}
$$

$$
(i=1, \ldots, m \text { ve } j=1, \ldots, p)
$$

$N=\left[\begin{array}{cc}n_{11} n_{12} \ldots & n_{1 p} \\ n_{21} n_{22} \ldots & n_{2 p} \\ \cdot & \\ \cdot & \cdot \\ n_{m 1} n_{m 2} \ldots & n_{m p}\end{array}\right]$

Table 3: Normalized Matrix

\begin{tabular}{|l|l|l|l|l|l|l|l|l|l|}
\hline & $\begin{array}{l}\text { Sharehold } \\
\text { ers } \\
\text { Equity/Tot } \\
\text { al Assets }\end{array}$ & $\begin{array}{l}\text { Financial } \\
\text { Investme } \\
\text { nts of } \\
\text { Risk Life } \\
\text { Insurance } \\
\text { Policy/To } \\
\text { tal Assets }\end{array}$ & $\begin{array}{l}\text { Short } \\
\text { Term } \\
\text { Liabilitie } \\
\text { s/ Total } \\
\text { Assets }\end{array}$ & $\begin{array}{l}\text { Pension } \\
\text { Technical } \\
\text { Income/Pens } \\
\text { ion Technical } \\
\text { Expense }\end{array}$ & $\begin{array}{l}\text { Net } \\
\text { Period } \\
\text { Profit/To } \\
\text { tal Assets }\end{array}$ & $\begin{array}{l}\text { Net Period } \\
\text { Profit/Sharehol } \\
\text { ders Equity }\end{array}$ & $\begin{array}{l}\text { Net } \\
\text { Period } \\
\text { Profit/ } \\
\text { Number } \\
\text { of } \\
\text { Sector } \\
\text { Employe } \\
\text { es }\end{array}$ & $\begin{array}{l}\text { (Pension } \\
\text { Technical } \\
\text { Income- } \\
\text { Pension } \\
\text { Technical } \\
\text { Expense)/Num } \\
\text { ber of } \\
\text { Participants }\end{array}$ & $\begin{array}{l}\text { Net Period } \\
\text { Profit / } \\
\text { Number of } \\
\text { Contracts }\end{array}$ \\
\hline $\mathbf{2 0 0 6}$ & 0,34 & 0,54 & 0,32 & 0,15 & 0,19 & 0,16 & 0,10 & $-0,79$ & 0,17 \\
\hline $\mathbf{2 0 0 7}$ & 0,33 & 0,46 & 0,31 & 0,19 & 0,40 & 0,35 & 0,25 & $-0,53$ & 0,32 \\
\hline $\mathbf{2 0 0 8}$ & 0,32 & 0,40 & 0,30 & 0,33 & 0,38 & 0,34 & 0,27 & 0,01 & 0,32 \\
\hline $\mathbf{2 0 0 9}$ & 0,30 & 0,35 & 0,33 & 0,34 & 0,34 & 0,32 & 0,26 & 0,03 & 0,31 \\
\hline $\mathbf{2 0 1 0}$ & 0,31 & 0,27 & 0,32 & 0,38 & 0,29 & 0,27 & 0,27 & 0,14 & 0,29 \\
\hline $\mathbf{2 0 1 1}$ & 0,37 & 0,23 & 0,31 & 0,33 & 0,28 & 0,22 & 0,29 & 0,00 & 0,29 \\
\hline $\mathbf{2 0 1 2}$ & 0,33 & 0,19 & 0,33 & 0,33 & 0,27 & 0,24 & 0,32 & 0,02 & 0,31 \\
\hline $\mathbf{2 0 1 3}$ & 0,29 & 0,16 & 0,33 & 0,26 & 0,24 & 0,24 & 0,26 & $-0,24$ & 0,25 \\
\hline $\mathbf{2 0 1 4}$ & 0,25 & 0,12 & 0,25 & 0,29 & 0,26 & 0,30 & 0,31 & $-0,14$ & 0,28 \\
\hline $\mathbf{2 0 1 5}$ & 0,23 & 0,09 & 0,25 & 0,31 & 0,27 & 0,33 & 0,34 & $-0,06$ & 0,29 \\
\hline $\mathbf{2 0 1 6}$ & 0,22 & 0,08 & 0,25 & 0,34 & 0,35 & 0,45 & 0,50 & 0,03 & 0,42 \\
\hline
\end{tabular}

After getting normalized matrix in TOPSIS method, we reached weighted normalized matrix by weighting each factor with its share in the total factors share.

$$
V=\left[\begin{array}{ccc}
v_{11} v_{12} & \ldots & v_{1 p} \\
v_{21} v_{22} & \ldots & v_{2 p} \\
\cdot & \\
\cdot & \\
v_{m 1} v_{m 2} & \ldots & v_{m p}
\end{array}\right]
$$


Table 4: Weighted Normalized Matrix

\begin{tabular}{|l|l|l|l|l|l|l|l|l|l|}
\hline & $\begin{array}{l}\text { Sharehold } \\
\text { ers } \\
\text { Equity/Tot } \\
\text { al Assets }\end{array}$ & $\begin{array}{l}\text { Financial } \\
\text { Investme } \\
\text { nts of } \\
\text { Risk Life } \\
\text { Insurance } \\
\text { Policy/To } \\
\text { tal Assets }\end{array}$ & $\begin{array}{l}\text { Short } \\
\text { Term } \\
\text { Liabilitie } \\
\text { s/Total } \\
\text { Assets }\end{array}$ & $\begin{array}{l}\text { Pension } \\
\text { Technical } \\
\text { Income/Pens } \\
\text { ion Technical } \\
\text { Expense }\end{array}$ & $\begin{array}{l}\text { Net } \\
\text { Period } \\
\text { Profit/To } \\
\text { tal Assets }\end{array}$ & $\begin{array}{l}\text { Net Period } \\
\text { Profit/Sharehol } \\
\text { ders Equity }\end{array}$ & $\begin{array}{l}\text { Net } \\
\text { Period } \\
\text { Profit/ } \\
\text { Number } \\
\text { of Sector } \\
\text { Employe } \\
\text { es }\end{array}$ & $\begin{array}{l}\text { (Pension } \\
\text { Technical } \\
\text { Income- } \\
\text { Pension } \\
\text { Technical } \\
\text { Expense)/Num } \\
\text { ber of } \\
\text { Participants }\end{array}$ & $\begin{array}{l}\text { Net Period } \\
\text { Profit / } \\
\text { Number of } \\
\text { Contracts }\end{array}$ \\
\hline $\mathbf{2 0 0 6}$ & 0,04 & 0,06 & 0,04 & 0,02 & 0,02 & 0,02 & 0,01 & $-0,09$ & 0,02 \\
\hline $\mathbf{2 0 0 7}$ & 0,04 & 0,05 & 0,03 & 0,02 & 0,04 & 0,04 & 0,03 & $-0,06$ & 0,04 \\
\hline $\mathbf{2 0 0 8}$ & 0,04 & 0,04 & 0,03 & 0,04 & 0,04 & 0,04 & 0,03 & 0,00 & 0,04 \\
\hline $\mathbf{2 0 0 9}$ & 0,03 & 0,04 & 0,04 & 0,04 & 0,04 & 0,04 & 0,03 & 0,00 & 0,03 \\
\hline $\mathbf{2 0 1 0}$ & 0,03 & 0,03 & 0,04 & 0,04 & 0,03 & 0,03 & 0,03 & 0,02 & 0,03 \\
\hline $\mathbf{2 0 1 1}$ & 0,04 & 0,03 & 0,03 & 0,04 & 0,03 & 0,02 & 0,03 & 0,00 & 0,03 \\
\hline $\mathbf{2 0 1 2}$ & 0,04 & 0,02 & 0,04 & 0,04 & 0,03 & 0,03 & 0,04 & 0,00 & 0,03 \\
\hline $\mathbf{2 0 1 3}$ & 0,03 & 0,02 & 0,04 & 0,03 & 0,03 & 0,03 & 0,03 & $-0,03$ & 0,03 \\
\hline $\mathbf{2 0 1 4}$ & 0,03 & 0,01 & 0,03 & 0,03 & 0,03 & 0,03 & 0,03 & $-0,02$ & 0,03 \\
\hline $\mathbf{2 0 1 5}$ & 0,03 & 0,01 & 0,03 & 0,03 & 0,03 & 0,04 & 0,04 & $-0,01$ & 0,03 \\
\hline $\mathbf{2 0 1 6}$ & 0,02 & 0,01 & 0,03 & 0,04 & 0,04 & 0,05 & 0,06 & 0,00 & 0,05 \\
\hline
\end{tabular}

By TOPSIS method, after getting the weighted normalized matrix, it is necessary to identify maximum values of each column on condition of sticking to the structure of problem. These maximum values are ideal solution values. After that, minimum values of each column are obtained. These become the negative solution values (Özdemir, 2015).

Ideal Solution Values:

$$
A^{+}=\left\{v_{1}^{+}, v_{2}^{+}, \ldots, v_{p}^{+}\right\}
$$

Negative Ideal Solution Values:

$$
A^{-}=\left\{v_{1}^{-}, v_{2}^{-}, \ldots, v_{p}^{-}\right\}
$$

After identifying ideal and negative ideal solution values, we reached to the results in Table 5.

Table 5: Ideal and Negative Ideal Solution Points

\begin{tabular}{|l|l|l|l|l|l|l|l|l|l|}
\hline & $\begin{array}{l}\text { Sharehold } \\
\text { ers } \\
\text { Equity/Tot } \\
\text { al Assets }\end{array}$ & $\begin{array}{l}\text { Financial } \\
\text { Investmen } \\
\text { ts of Risk } \\
\text { Life } \\
\text { Insurance } \\
\text { Policy/Tot } \\
\text { al Assets }\end{array}$ & $\begin{array}{l}\text { Short } \\
\text { Term } \\
\text { Liabilitie } \\
\text { / Total } \\
\text { Assets }\end{array}$ & $\begin{array}{l}\text { Pension } \\
\text { Technical } \\
\text { Income/Pensi } \\
\text { on Technical } \\
\text { Expense }\end{array}$ & $\begin{array}{l}\text { Net } \\
\text { Period } \\
\text { Profit/Tot } \\
\text { al Assets }\end{array}$ & $\begin{array}{l}\text { Net Period } \\
\text { Profit/Sharehold } \\
\text { ers Equity }\end{array}$ & $\begin{array}{l}\text { Net } \\
\text { Period } \\
\text { Profit/ } \\
\text { Number } \\
\text { of Sector } \\
\text { Employe } \\
\text { es }\end{array}$ & $\begin{array}{l}\text { (Pension } \\
\text { Technical } \\
\text { Income- } \\
\text { Pension } \\
\text { Technical } \\
\text { Expense)/Num } \\
\text { ber of } \\
\text { Participants }\end{array}$ & $\begin{array}{l}\text { Net } \\
\text { Period } \\
\text { Profit / } \\
\text { Number } \\
\text { of } \\
\text { Contrac } \\
\text { ts }\end{array}$ \\
\hline $\begin{array}{l}\text { Ideal } \\
\text { Solution }\end{array}$ & 0,04 & 0,06 & 0,03 & 0,04 & 0,04 & 0,05 & 0,06 & 0,02 & 0,05 \\
\hline $\begin{array}{l}\text { Negative } \\
\text { Ideal } \\
\text { Solution }\end{array}$ & 0,02 & 0,01 & 0,04 & 0,02 & 0,02 & 0,02 & 0,01 & $-0,09$ & 0,02 \\
\hline
\end{tabular}


After ideal and negative ideal solution values have been identified, the distance from those points is obtained by the calculation of Euclidean distance.

$$
d_{i \bar{i}}=\sqrt{\sum_{k=1}^{p}\left(x_{i k}-x_{j k}\right)^{2}}
$$

For each decision point, relative proximity to the ideal solution is calculated at this stage. The proximity will be between 0 and 1 . As long as the result gets close to 1 , it approaches to the ideal solution. However, if it comes close to 0 , it approaches to the negative solution. The distances of the years examined from the ideal and negative ideal solutions are calculated and the results are represented in Table6.

Ideal Distance:

$$
S_{i}^{+}=\sqrt{\sum_{j=1}^{n}\left(v_{i j}-v_{j}^{+}\right)^{2}}
$$

Negative Ideal Distance:

$$
S_{i}^{-}=\sqrt{\sum_{j=1}^{n}\left(v_{i j}-v_{j}^{-}\right)^{2}}
$$

Table 6: Distances from Ideal and Negative Ideal Solutions in the Years Examined

\begin{tabular}{|l|l|l|}
\hline Years & Distance From Ideal Solution & Distance From Negative Ideal Solution \\
\hline $\mathbf{2 0 0 6}$ & 0,125311 & 0,053138 \\
\hline $\mathbf{2 0 0 7}$ & 0,084367 & 0,065976 \\
\hline $\mathbf{2 0 0 8}$ & 0,039288 & 0,104841 \\
\hline $\mathbf{2 0 0 9}$ & 0,043412 & 0,104071 \\
\hline $\mathbf{2 0 1 0}$ & 0,049268 & 0,112461 \\
\hline $\mathbf{2 0 1 1}$ & 0,056027 & 0,096844 \\
\hline $\mathbf{2 0 1 2}$ & 0,055219 & 0,099313 \\
\hline $\mathbf{2 0 1 3}$ & 0,076964 & 0,066858 \\
\hline $\mathbf{2 0 1 4}$ & 0,068693 & 0,080414 \\
\hline $\mathbf{2 0 1 5}$ & 0,064866 & 0,090901 \\
\hline $\mathbf{2 0 1 6}$ & 0,055954 & 0,11358 \\
\hline
\end{tabular}

At the final stage of TOPSIS method, performance scores of each alternative are calculated by the formula below. Scores of the years examined calculated by TOPSIS method, are represented in Table 7.

$$
C_{\mathrm{I}}^{*}=\frac{S_{\mathrm{I}}^{-}}{S_{\mathrm{I}}^{-}+S_{\dot{\mathrm{I}}}^{*}}
$$

$0 \leq C_{\mathrm{I}}^{*} \leq 1$

$i=1 \ldots n$ 
Table 7: Performance Results of the Years Examined

\begin{tabular}{|l|l|}
\hline $\mathbf{2 0 0 6}$ & 0,297776201 \\
\hline 2007 & 0,438836793 \\
\hline 2008 & 0,727408624 \\
\hline 2009 & 0,705646351 \\
\hline 2010 & 0,695366284 \\
\hline $\mathbf{2 0 1 1}$ & 0,633502457 \\
\hline $\mathbf{2 0 1 2}$ & 0,642671561 \\
\hline $\mathbf{2 0 1 3}$ & 0,464863633 \\
\hline $\mathbf{2 0 1 4}$ & 0,539302873 \\
\hline $\mathbf{2 0 1 5}$ & 0,583570322 \\
\hline $\mathbf{2 0 1 6}$ & 0,669954236 \\
\hline
\end{tabular}

When performance results of the years are sorted, the success rating has shaped as it is represented in Table 8.

Table 8: Performance Ranking of the Years Examined

\begin{tabular}{|l|l|}
\hline $\mathbf{2 0 0 6}$ & 11 \\
\hline $\mathbf{2 0 0 7}$ & 10 \\
\hline $\mathbf{2 0 0 8}$ & 1 \\
\hline 2009 & 2 \\
\hline $\mathbf{2 0 1 0}$ & 3 \\
\hline $\mathbf{2 0 1 1}$ & 6 \\
\hline $\mathbf{2 0 1 2}$ & 5 \\
\hline $\mathbf{2 0 1 3}$ & 9 \\
\hline $\mathbf{2 0 1 4}$ & 8 \\
\hline $\mathbf{2 0 1 5}$ & 7 \\
\hline $\mathbf{2 0 1 6}$ & 4 \\
\hline
\end{tabular}

\section{FINDINGS AND DISCUSSIONS}

As a result of this study where the performance of Turkish Private Pension Sector between 2006 and 2016 is analysed by a multi criteria decision-making method, TOPSIS, it can be concluded that among 11 years examined, 2008 has the highest performance score while 2006 has the lowest.

In Turkey, private pension companies made loss during the first years of private pension system that started in 2003. It is thought that the loss of companies have led to the performance decrease in 2006. In the following years, with the sector making profit, performance scores of each year and their place in performance ranking have increased.

Besides the fact that 2008 has the highest performance score among the years examined, it is observed that the scores of 2009 and 2010 are notably good. The costs that the sector bare during its first years, have reached to a break-even point within 5-6 years and fund amounts have increased as well. These are thought to be the reasons behind those performance scores. Although 2008 is the year of global financial crisis, also 2009 and 2010 are the years when the effects of crisis still continued, private pension sector has increased its funds above $30 \%$ in both years.

Despite increasing funds, since it was the year of the financial crisis, the companies were deliberate and they started to manage more funds while keeping shareholders equity at the same level. This, therefore, have resulted in performance increase. 
When the results examined, it is observed that sector's performance have increased since 2013. In addition, the coefficient is thought to be state subsidy amounting to $25 \%$ of employees' paid contributions to private pension account, which was initiated on January 1st, 2013.

\section{REFERENCES}

Alptekin, N., Şıklar, E. (2009). Türk hisse senedi emeklilik yatrim fonlarinin çok kriterli performans değerlendirmesi: Topsis metodu. Dumlupınar Üniversitesi Sosyal Bilimler Dergisi .

Barrientos, A., Boussofiane, A. (2005). How efficient are the pension funds managers in Chile. Revista de Economia Contemporânea, 289311.

Barros, C. P., Garcia, M. T. (2006). Performance evaluation of pension funds management companies with DEA. Risk Management and Insurance Review, 165-188.

Barros, C. P., Ferro, G., Romero, C. (2008). Technical efficiency and heterogeneity of Argentina pension funds. Working Paper.

Bülbül, S. E., Baykal, K. B. (2017). Hayat dışı branşlarda faaliyet gösteren Türk sigorta şirketlerinin finansal performans analizi: Vikor yönetimi. $3^{\text {rd }}$ National Insurance and Actuarial Congress , (p. 1-9). Karabük.

Çiftçi, H. (2004). Türk sigorta sektörünün sorunlari; DEA analizi ile Türk sigorta şirketlerinin etkinlik düzeylerinin belirlenmesi. Çukurova Üniversitesi Sosyal Bilimler Dergisi, 121-149.

Dalkılıç, N. (2012). Türkiye'de hayatdişi sigortacilik sektöründe etkinlik analizi. Muhasebe ve Finasman Dergisi, 71-90.

Demirelli, E. (2010). TOPSIS çok kriterli karar verme sistemi: Türkiye'deki kamu bankalari üzerine bir uygulama. Girişimcilik ve Kalkınma Dergisi, 101-112.

Gürol, B., Hazar, A. (2017). Türkiye'de faaliyet gösteren hayat dişi ve hayat emeklilik sigorta şirketlerinin performanslarinin karşılaştırılması. $3^{\text {rd }}$ National Insurance and Actuarial Congress, (p. 17-22). Karabük.

İşseveroğlu, G., Hatunoğlu, Z. (2010). Türkiye'de bireysel emeklilik sisteminin makro ekonomik dinamiklere etkisi kapsamında Swot analizi. Muhasebe ve Finansman Dergisi, 155.

Karakaya, A., Kurtaran, A., Dağlı, H. (2014). Bireysel emeklilik şirketlerinin veri zarflama yönetmiyle etkinlik ölçümü: Türkiye örneği. Yönetim ve Ekonomik Araştırmalar Dergisi.

Kırkağaç, M., Dalkılıç, N. (2017). Türkiye'de faaliyet gösteren emeklilik şirketlerinin performanslarinin temel bileşenler analizi ve kümeleme analizi ile karşilaştırılması . $3^{\text {rd }}$ National Insurance and Actuarial Congress , (p. 130-136). Karabük.

Köse, A., Türkel, U. (2017). Gri ilişkisel analiz yöntemi ile hayat dişi branşlarda Türk sigorta sektörünün değerlendirilmesi. $3^{\text {rd }}$ National Insurance and Actuarial Congress, (p. 10-16). Karabük.

Özaktaş, F. D. (2017). Hayat dişi sigorta sektöründe etkinlik analizi: Türkiye uygulaması. Çukurova Üniversitesi Sosyal Bilimler Enstitüsü Dergisi , 30-44.

Özdemir, M. (2015). TOPSIS. Çok kriterli karar verme yöntemleri (p. 134). içinde Bursa: Dora Kitap.

Peker, İ., Baki, B. (2011). Gri ilişkiler analiz yönetmiyle Türk sigortacilik sektöründe performans ölçümü. Karadeniz Teknik Üniversitesi İktisadi ve İdari İncelemeler Dergisi, 1-17.

Teresa, M., Garcia, M. (2010). Efficiency evaluation of the Portuguese pension funds management companies. Journal of International Financial Markets, 259-266.

Wu, D., Yang, Z., Vela, S., Liang, L. (2007). Simultaneous analysis of production and investment performance of Canadian life and health insurance companies using DEA. Computers and Operations Research, 180-198. 